Natalia Jackowska

Instytut Zachodni

\title{
Pojednanie i Caritas. Kościoły w życiu społecznym zjednoczonych Niemiec oraz w dialogu z Polską
}

Ostatnie ćwierćwiecze to okres niezwykle dynamicznych zmian dokonujących się w życiu religijnym i konfesyjnym ponownie zjednoczonych Niemiec. Ojczyzna Reformacji, tradycyjnie kojarzona z dwoma wyznaniami chrześcijańskimi, stała się po 1990 roku nie tylko krajem o znacznej liczbie ateistów i bezwyznaniowców oraz powiększającym się odsetku muzułmanów, ale doświadczyła też napływu przedstawicieli różnych odłamów prawosławia oraz judaizmu. Borykające się z malejącą liczbą wyznawców Kościoły chrześcijańskie zachowują jednak głos w debatach publicznych dotyczących życia społecznego oraz imponderabiliów, jakie powinny wpływać na kształt wspólnoty państwowej oraz relacji z innymi narodami. Stanowiące owoce wcześniejszych tradycji, doświadczenia wyniesione w okresu republiki bońskiej powodują, że kultura dialogu kościelnego pozostaje wzorem dla innych krajów Europy, także dla kontaktów na płaszczyźnie konfesyjnej i społecznej z Polską, a pośrednio promieniuje na narody Europy Wschodniej. Stanowisko wspólnot religijnych wobec procesu integracji europejskiej, zagadnienia pojednania i dialogu, m.in. z krajami dawnego ZSRR, działalność charytatywna (m.in. pomoc uchodźcom) i dialog społeczny to obszary, na których Kościoły niemieckie z powodzeniem współdziałają także w wymiarze międzynarodowym. Szczególnie warto podkreślić przenikanie się w tych sferach refleksji intelektualnej, działalności kulturalnej i kulturotwórczej oraz praktycznej pomocy świadczonej potrzebującym. W kontaktach z Polską spuścizna istotnych kroków podjętych przez Kościoły na rzecz pojednania obu narodów, począwszy od Orędzia biskupów z 1965 roku ukazuje ciągle swój aktualny wymiar, godny nie tylko rocznicowych upamiętnień. Model międzynarodowej współpracy, 
wyrosły w jakże odmiennych realiach politycznych i cywilizacyjnych, jest wzorem dla innych narodów i wspólnot wyznaniowych.

Zamierzeniem niniejszego opracowania jest krótkie przedstawienie aktualnej sytuacji konfesyjnej i religijnej w Niemczech 25 lat od zjednoczenia oraz ukazanie przykładu instytucjonalnego dialogu z Kościołem katolickim w Polsce jako fundamentu powojennego porozumienia i dialogu polsko-niemieckiego. Jego geneza, sięgająca Orędzia polskich biskupów opublikowanego na zakończenie Soboru Watykańskiego II, stała się punktem wyjścia dla wielopłaszczyznowych kontaktów, które choć w trudnych okolicznościach, tworzyły podstawę porozumienia, realizowanego już w warunkach wolności i suwerenności. Dokument z 1965 roku zachowuje swą rangę także obecnie, będąc inspiracją i wzorem dla innych narodów. Z kolei aktualne wyzwanie pomocy napływającym do Niemiec uchodźcom i migrantom jest przykładem praktycznej implementacji roli Kościołów w życiu społecznym, którą - mimo, czy wbrew danym statystycznym wskazującym malejącą liczbę członków - należy uznać za świadectwo dawane wyznawanym wartościom.

Doświadczeniem zjednoczonych 3 października 1990 roku Niemiec stała się nie tylko realizacja artykułowanego wcześniej marzenia, , aby zrosło się to, co do siebie należy", ale także wielopłaszczyznowe przeobrażenia wynikające z dynamiki przemian o znacznie szerszym, nie tylko europejskim, kontekście. Interesującym obszarem przemian, które wykroczyły daleko poza proste następstwa połączenia dwóch państw niemieckich i zamieszkujących je społeczeństw, są Kościoły, związki wyznaniowe oraz życie religijne Republiki Federalnej Niemiec. Niepełne, o ile nie zgoła fałszywe, okazują się dziś próby zdefiniowania życia religijnego Niemiec wyłącznie w nawiązaniu do tradycji Reformacji, podobnie jak nie sposób mówić o Niemczech jako kraju słabnącego katolicyzmu. Zaskoczenie może wywołać bogactwo współczesnego niemieckiego prawosławia, niełatwo nakreślać charakter niemieckiego islamu, a nawet odrodzona niemal z niebytu społeczność wyznawców judaizmu nie poddaje się jednoznacznym definicjom. Mapa konfesyjna państwa między Łabą a Renem istotnie różni się od tej sprzed ćwierćwiecza, a konfrontacja religii i wyznań z także niejednoznacznymi zjawiskami bezwyznaniowości i ateizmu wskazuje na inspirującą do wielu analiz, złożoną sytuację tej sfery życia społecznego Niemiec ${ }^{1}$.

1 Szersze omówienie zmian kształtujących religijność zjednoczonych Niemiec patrz: Religie i religijność w zjednoczonych Niemczech, [w:] J. Dobrowolska-Polak, N. Jackowska, M. Nowosielski, M. Tujdowski, Niemcy po zjednoczeniu. Społeczeństwo - wielokulturowość - religie, Poznań 2013, s. 183-253. 
Pochodzące z lipca 2015 roku dane liczbowe dotyczące reprezentowanych wśród 81,1 mln mieszkańców RFN religii i wyznań wskazują na nieznaczną przewagę katolików (23,9 mln osób) nad protestantami $(23 \mathrm{mln})$. Około 288 tys. wyznawców przynależy do wolnych Kościołów ewangelickich, natomiast 1,7 mln wiernych tworzy wspólnoty prawosławne różnych obrządków oraz narodowości. Na ok. 500 tys. szacuje się wyznawców pozostałych Kościołów i wspólnot chrześcijańskich. Trudniej oszacowaćliczebność wyznawców islamu - dane pochodzące jeszcze z 2009 roku wskazywały na przedział od 3,8 do 4,3 mln, w tym ok. 2,5 mln osób pochodzenia tureckiego. Spośród wyznawców islamu ok. 1,8 mln osób posiadało już niemieckie obywatelstwo. Liczbę wyznawców religii mojżeszowej szacowano na ok. 100 tys. osób². Nietrudno zauważyć, że pozostała część, niemal jedna trzecia mieszkańców Niemiec, to osoby bezwyznaniowe, nierzadko w kolejnym pokoleniu. Spuścizna historycznych podziałów na protestancką północ i katolickie południe, dopełniona po zjednoczeniu elementem bezwyznaniowego wschodu ukazuje istotne zróżnicowanie w obrazie religijnym poszczególnych krajów federacji. Trzeba też pamiętać o sporych różnicach dotyczących liczebności wyznawców poszczególnych konfesji w krajach federacji: katolicy stanowią od 3 do 10 procent populacji wschodnich krajów, na północy tworzą grupę liczącą od 6 (Schleswig-Holstein) do 18 (Dolna Saksonia) procent mieszkańców, a na południu ich odsetek sięga 53 procent w Bawarii i 61 procent w Kraju Saary ${ }^{3}$.

Te ledwie zasygnalizowane, dynamiczne i głębokie zmiany w obrazie życia religijnego Niemiec ćwierć wieku po zjednoczeniu są jedynie tłem dla zasadniczego pytania o postawę największych Kościołów - katolickiego oraz ewangelickiego, reprezentowanego przez Evangelische Kirche in Deutschland (EKD) - wobec aktualnego wymiaru pojednania jako zadania wspólnot wyznaniowych w Europie i świecie oraz stanowiska i działań podejmowanych wobec fali migrantów docierających do Europy w następstwie wydarzeń na Bliskim Wschodzie. Jakakolwiek próba uchwycenia aktualnej sytuacji Kościołów w Niemczech, także w porównaniu z sytuacją konfesyjną w innych krajach Europy, byłaby bowiem spłycona, gdyby ograniczała się do stwierdzenia malejącej liczby wyznawców oraz słabnącego oddziaływania na poglądy oraz postawy etyczne współczesnych społeczeństw. Nawet powyższy, skrótowy zarys zmian zachodzących w religijności Niemiec wskazuje, że laicyzacja nie jest głównym i - można zaryzykować tezę - najważniejszym zjawiskiem determinującym obecną sytuację.

2 Dane z lat 2009-2014 przytoczone w: Katholische Kirche in Deutschland, Zahlen und Fakten 2014/2015, Arbeitshilfen 275, s. 6.

3 Tamże, s. 7. 
Z kolei zagadnienia pojednania oraz postawy wobec migrantów nie są niczym nowym dla Kościołów chrześcijańskich w Niemczech, zarówno w okresie po zakończeniu II wojny światowej, jak i po 1989 roku. Wydarzenia ostatnich miesięcy i lat przynaglają raczej do adaptacji działań i refleksji do aktualnych potrzeb. Z perspektywy „tu i teraz” mogą okazać się doświadczeniem ożywiającym niemieckie chrześcijaństwo, podobnie jak miało to miejsce kilkadziesiąt lat wcześniej w relacjach z narodami skrzywdzonymi podczas wojny.

\section{Pojednanie zadaniem (nie tylko) Kościołów}

Sygnowane przez 36 polskich hierarchów Kościoła katolickiego 18 listopada 1965 roku w Rzymie Orędzie biskupów polskich do ich niemieckich Braci $w$ Chrystusie przeszło do historii jako wezwanie do przebaczenia i pojednania narodów, które doświadczyły ogromu zbrodni i nienawiści, także dwadzieścia lat po zakończeniu wojny utrudniającego podjęcie relacji międzyludzkich i międzynarodowych. Geneza Orędzia, jego przygotowanie, a przede wszystkim reakcje, $\mathrm{z}$ jakimi się spotkało, także ze strony niemieckich adresatów, są stosunkowo dobrze znane; również dostępne opracowania dotyczące tego epizodu kończącego się Soboru Watykańskiego II i jego następstw relacjonują te wydarzenia w sposób szczegółowy i pogłębiony ${ }^{4}$. Warto w tym miejscu zwrócić uwagę przede wszystkim na aktualną i inspirującą - aż do dziś - rolę tego ważnego dokumentu, stąd pominięcie innych aspektów, m.in. reakcji nań ówczesnych władz polskich.

Rzadziej podejmowaną kwestią są też reakcje, z jakimi Orędzie spotkało się w Republice Federalnej Niemiec. Płynące z ław soborowych słowa o pojednaniu i wybaczeniu wpisały się tam w kontekst społeczny oraz polityczny, odmienny jednak od polskich zmagań z propagandą oraz brakiem mechanizmów demokratycznych i swobody wypowiedzi. Blisko dziesięciomilionowa rzesza przesiedleńców zamieszkujących RFN, spośród których niemal połowa wskazywała swoje poprzednie miejsca zamieszkania na terenach powojennej Polski ${ }^{5}$ oraz złożone meandry relacji, a raczej strategii politycznych dyktujących postawę Zachodnich Niemiec wobec Związku Radzieckiego, Niemieckiej Republiki Demokratycznej i Polski, a także całego bloku wschodniego

$4 \quad$ P. Madajczyk, Na drodze do pojednania. Wokół orędzia biskupów polskich do biskupów niemieckich z 1965 roku, Warszawa 1994; B. Kerski, T. Kycia, R. Żurek (red.); „Przebaczamy i prosimy o przebaczenie”. Orędzie biskupów polskich i odpowiedź niemieckiego episkopatu z 1965 roku. Geneza, kontekst, spuścizna, Olsztyn 2006.

5 Niemcy współczesne. Zarys encyklopedyczny, Poznań 1999, s. 908. 
uniemożliwiły klarowną i jednoznaczną odpowiedź na gest polskich biskupów. Z całą pewnością jednak Orędzie wprowadziło nowe impulsy do wewnątrzniemieckiej debaty krystalizującej politykę wschodnią. Choć należały one do sfery etycznej, sam fakt ich pojawienia się ze strony polskiego Episkopatu zmuszał do podjęcia kolejnych kroków na rzecz porozumienia. Najlepszym tego dowodem stała się choćby działalność środowiska intelektualistów katolickich, dzięki którym w 1968 roku powstało Memorandum z Bensberg, czy równolegle podejmowane inicjatywy kręgów ewangelickich.

Kontekst, który w ostatnich latach zdaje się dominować w spojrzeniu na Orędzie, przesądzając o jego ponadczasowym znaczeniu, związany jest $\mathrm{z}$ jego etycznym wydźwiękiem oraz następstwami leżącymi nie tylko w sferze zwrotów politycznych, ale ich głęboko ludzkich fundamentów, bez których niemożliwa jest autentyczna zmiana. Nawiązujące bezpośrednio do wielkiego gestu z 1965 roku dokumenty hierarchii Kościoła katolickiego z Polski oraz Niemiec, najczęściej związane $\mathrm{z}$ jego upamiętnieniem, powstawały w diametralnie odmiennych warunkach systemowych i z tej perspektywy traktują Orędzie jako genezę procesu, który doprowadził narody z obu stron Odry do pokojowej koegzystencji w zjednoczonej Europie. Współczesnych autorów tych deklaracji łączy natomiast świadomość, że nowe wyzwania potrzebują podobnie etycznego fundamentu, a rzeczywistość często boleśnie dowodzi, że porozumienie i pojednanie nie są kwestią jednorazowego aktu, lecz wymagają mozolnej, codziennej troski. Nie inna była myśl towarzysząca w 1965 roku Orędziu, bo i apel o odejście od wyrachowanej kalkulacji i oparcie relacji między dwoma narodami na fundamencie przebaczenia nie należał wówczas, i nawet dziś nie należy, do arsenału środków typowych dla polityki i stosunków międzynarodowych. Dlatego na konsekwencje Orędzia z 1965 roku trzeba spojrzeć kategoriami długiego trwania Fernanda Braudela, jak na proces i dziś wymagający pielęgnowania: „Wydarzenie ma charakter wybuchowy, jest »dźwięczną nowiną", jak mawiano w XVI wieku. Swoim przesadnym dymem wypełnia świadomość współczesnych, ale nie trwa wcale, zaledwie dostrzec się daje jego płomień. (...) Wydarzenie może przecież dźwigać w sobie szereg znaczeń lub przekazów. Daje niekiedy świadectwo ruchom bardzo głębokim i poprzez grę, czasem pozorną, "przyczyn« i »skutków«, tak drogą wczorajszym historykom, przywłaszcza sobie wymiar czasowy rozciągliwie, wiąże się - swobodnie lub nie - z całym łańcuchem innych wydarzeń, wydarzeń rzeczywistości podskórnych, których nie sposób, jak się zdaje, od siebie rozdzielić."

6 F. Braudel, Historia i nauki społeczne: długie trwanie, [w:] F. Braudel, Historia i trwanie, Warszawa 1971, s. 50. 
Wydźwięk Orędzia zdominowało wezwanie do przebaczenia. Ale jego wewnętrzna logika oparta była na trzech filarach: poznaniu prawdy, podjęciu wysiłku zrozumienia i odwagi spojrzenia w przyszłość. Przesłanie polskich biskupów było bodaj pierwszym dokumentem tej rangi, który trafił do polskiej opinii publicznej, przedstawiającym historię polsko-niemieckiego sąsiedztwa w sposób odmienny od narzucanego przez propagandę PRL obrazu odwiecznej, tysiącletniej wrogości. O ponadczasowej wartości dokumentu zdecydowała jednak propozycja wprowadzenia do świata polityki kategorii aksjologicznych odmiennych od oficjalnej ideologii. Orędzie odwoływało się do sumień i kładło bardzo wysoko poprzeczkę wymagań etycznych. Było to oczywiście nie do pogodzenia z doktryną marksistowskiego materializmu i wywołało opór rządzących Polską Ludową. Ambicją autorów Orędzia nie było jednak zastępowanie polityków, lecz nadanie polityce trwałej, etycznej motywacji - dziś rozumiemy, że nie są to kategorie wykluczające się, lecz uzupełniające. Ten właśnie uniwersalny aspekt zadecydował o przetrwaniu Orędzia w świadomości historycznej i jego inspirującej mocy - także dziś, po ponad 50 latach - odniesienie wymogów ewangelicznych do sfery politycznej stanowiło propozycję jej przewartościowania. Trzeba też spojrzeć na Orędzie biskupów jako owoc Soboru Watykańskiego II, a nawet wcześniejszej atmosfery duchowego i intelektualnego otwarcia na świat, jaka wiąże się $\mathrm{z}$ osobą papieża Jana XXIII. Inicjator aggiornamento i autor encykliki $\mathrm{Pa}$ cem in terris zrewolucjonizował Kościół dzięki małym krokom i symbolom, a skodyfikowane przez Sobór sposoby obecności Kościoła w świecie wybiegały poza sferę czysto sakralną.

Należy także pamiętać, że już w połowie lat 60. przesłanie polskich biskupów nie powstało w próżni. Poprzedziła je dyskusja toczona w kręgach ewangelickich RFN na temat integracji rodaków wysiedlonych z ziem wschodnich. Jednym $\mathrm{z}$ ważniejszych dokumentów tej debaty było datowane na 6 listopada 1961 roku memorandum z Tybingi, przygotowane przez duchownych i świeckich intelektualistów związanych z EKD, spośród których można wymienić prof. Ludwiga Raisera, prof. Carla Friedricha von Weizsäckera oraz Klausa von Bismarcka. Efektem czteroletnich debat stało się stanowisko instytucjonalne EKD wyrażone 1 października 1965 roku w memorandum $O$ sytuacji wypędzonych $i$ stosunku narodu niemieckiego do swoich wschodnich sąsiadów. Dokument podejmował kwestię wypędzonych, nie unikając samokrytyki Kościoła odnoszącej się do trudności z integrowaniem tych rzesz ludzi w nowych warunkach. Odrębny rozdział traktował o powojennej sytuacji terenów „po tamtej stronie Odry i Nysy” oraz o aspektach prawnych i prawnomiędzynarodowych w relacjach ze wschodnim sąsiadem. 
Wskazywano na wzajemne ograniczanie dyskusji, obstawanie przy przeciwnych stanowiskach prawnych, które nie rozwija dialogu i dlatego nawoływano do szukania nowych rozwiązań, pozwalających znaleźć równowagę relacji i pokojowe współżycie Polaków i Niemców w przyszłości. Takie „małe” kroki podejmowane były w latach 60. i 70. po obu stronach Odry i Nysy Łużyckiej, zarówno w RFN, jak i - na miarę skromnych możliwości - w NRD. Kontakty i wypowiedzi hierarchów, inicjatywy intelektualistów, podróże studyjne młodzieży (często nieformalne, których pomysłodawcami byli działacze kościelni z NRD) miały wagę kropli drążącej skałę. Mimo różnic i asymetrii tworzyły obszary współpracy, która w pełni możliwa stała się dzięki przełomowi systemowemu w 1989 roku.

U progu tej zmiany słowa Orędzia pojednania przypomniano w oświadczeniu katolików polskich i niemieckich w pięćdziesiątą rocznicę wybuchu II wojny światowej zatytułowanym $O$ wolność, sprawiedliwość i pokój w Europie, w którym doceniony został czas pionierskich inicjatyw i spotkań. „Patrzymy już na siebie inaczej. Od tego czasu uczyniliśmy niejeden krok ku sobie. Ożywiły się kontakty między środowiskami katolickimi, organizacjami i prywatnymi osobami w Polsce i Republice Federalnej Niemiec; wytworzyły się trwałe przyjaźnie. Katolicy niemieccy z żywym zainteresowaniem obserwowali narodziny "Solidarności«, wielkiego ruchu społecznego, który porwał miliony ludzi w Polsce i pokojowymi środkami osiągnął zmiany polityczne i społeczne. Po wprowadzeniu stanu wojennego, który sparaliżował Polskę, chrześcijańska solidarność nie zawiodła w potrzebie - pospieszyła z konkretną pomocą, niosąc ją niezliczonej rzeszy ludzi”" Nierozwiązane pozostawały jednak zasadnicze kwestie samostanowienia narodów, będące konsekwencją II wojny światowej i podziału jałtańskiego. W gronie sygnatariuszy dokumentu w sierpniu 1989 roku znaleźli się intelektualiści i działacze katoliccy, którzy nie uchylili się od podjęcia odpowiedzialności za kształt postulowanych przemian, m.in.: Władysław Bartoszewski, Andrzej Drawicz, Kazimierz Dziewanowski, Stefan Frankiewicz, Krzysztof Kozłowski, Tadeusz Mazowiecki, Mieczysław Pszon, Andrzej Szczypiorski, ks. Józef Tischner, Wojciech Wieczorek czy Kazimierz Wóycicki.

Przypomnienie wezwania do pojednania towarzyszącego kończącemu się Soborowi Watykańskiemu II w oświadczeniu u progu fundamentalnych przewartościowań w 1989 roku otwierało drugi rozdział funkcjonowania Orędzia

7 O wolność, sprawiedliwość i pokój w Europie. Oświadczenie katolików polskich i niemieckich w pięćdziesiątą rocznicę wybuchu II wojny światowej, Warszawa-Bonn, sierpień 1989 r., „Więź” 1999, nr 9, s. 17-21. 
biskupów w myśli politycznej oraz świadomości społecznej. Przywołując wspólne chrześcijańskie korzenie europejskiej tożsamości, a także powikłaną historię ostatnich dziesięcioleci, Polacy i Niemcy wnosili do dyskusji o przyszłości Europy nowy impuls w postaci mozolnie wypracowanego porozumienia. Istotne okazały się dwa zastrzeżenia, poczynione przez autorów oświadczenia z 1989 roku: „Nie wolno nam zapominać o okropnościach i barbarzyństwie, jakie zaistniały w historii naszych narodów. Nie wolno nam jednak patrzeć wyłącznie w przeszłość" ${ }^{\prime}$. Ostatnie ćwierćwiecze udowodniło wagę tych zastrzeżeń, a także prawdę o pojednaniu jako długotrwałym procesie, wymagającym ciągłej dbałości. Sfera wartości pozostała (mimo wielu prób marginalizowania) jednym z fundamentów zarówno porozumienia polsko-niemieckiego, jak i integracji europejskiej. Dotykające tych procesów kryzysy tylko potwierdzają prawdę o antropologicznych źródłach przemian historycznych.

Odważne słowa Orędzia długo czekały na swoje dopowiedzenie we wspólnym dokumencie Episkopatów Polski i Niemiec. Podpisane przez kard. Józefa Glempa oraz bpa Karla Lehmanna 21 listopada 1995 roku w Warszawie Wspólne słowo polskich i niemieckich biskupów z okazji trzydziestej rocznicy wymiany listów (1965-1995) ${ }^{9}$ doceniło dialog chrześcijan świeckich i duchownych po obu stronach Odry (Akcja Znaki Pokuty, Pax Christi, Dzieło Maksymiliana Kolbego). Zasadniczą rolę w procesie porozumienia przypisano rosnącej liczbie osób, które w parafiach, diecezjach, związkach i ruchach kościelnych „dążyły do spotkania w duchu wspólnej wiary” zarówno w czasach podziału Niemiec, jak i po zjednoczeniu. Ruch „Solidarności” w Polsce, „wyrosły na podłożu moralnym, a nierzadko także i religijnym”, został uznany za przyczynę ostatecznego przełomu, a świadczona przez Niemców w latach kryzysu pomoc pozwalała na dalsze kontakty, także kulturalne i naukowe. W 1995 roku biskupi z wdzięcznością mówili o przezwyciężeniu totalitaryzmu i szansach kontynuowania pojednania - już w ramach jednoczącej się Europy. Zasadniczym motywem listu było poparcie Kościoła w obu krajach dla procesu odbudowy europejskiej jedności. W połowie lat 90 . droga do integracji była zawiła i niejednokrotnie stawiana pod znakiem zapytania, a groźba wprowadzenia nowych linii podziału w Europie, w Polsce czy w Kościele nie została zażegnana. Dostrzegano niedostatek edukacji obywatelskiej. Kościół w Polsce nie był gotowy, by w porę zabrać głos w debacie europejskiej, pierwsze oficjalne wypowiedzi pojawiły się dopiero w 1997 roku. Dlatego wspólna

Tamże, s. 21.

9 Wspólne słowo polskich i niemieckich biskupów z okazji trzydziestej rocznicy wymiany listów (1965-1995), tekst za: „Społeczeństwo” 1995, nr 4, s. 856-865. 
z niemieckimi biskupami wypowiedź o chrześcijańskiej odpowiedzialności za Europę zawarta w liście z 21 listopada 1995 roku należy do najwcześniejszych deklaracji w tej sprawie. Kładzie się w niej nacisk na dialog ekumeniczny, który uwiarygodnia Kościoły. Ponowiony apel o przebaczenie, by nigdy już duch nienawiści nie rozdzielił Polaków i Niemców potwierdzał, że nie chodzi o pojedyncze gesty, lecz długotrwały dialog i współpracę.

Drugim wspólnym dokumentem Episkopatów Polski i Niemiec jest podpisane 21 września 2005 roku w Fuldzie oraz trzy dni później we Wrocławiu wspólne oświadczenie z okazji 40. rocznicy wymiany listów: „podobnie jak kiedyś nasi Poprzednicy, tak i my dzisiaj czujemy się odpowiedzialni za proces porozumienia, pojednania i przyjaźni polsko-niemieckiej”10. Biskupi pisali wprost, że rocznica jest okazją do przeciwstawienia się nieodpowiedzialnej postawie, jaka zapanowała $\mathrm{w}$ relacjach polsko-niemieckich $\mathrm{w}$ ostatnim czasie: „odnosi się to także do poczynań tych, którzy podejmując je, odwołują się do sprawiedliwości". Wezwanie to jednoznacznie było kojarzone z ówczesną aktywnością kierowanego od 1998 roku przez deputowaną do Bundestagu z ramienia $C D U$ Erikę Steinbach Związku Wypędzonych w Niemczech. Planowane przezeń w Berlinie Centrum Przeciwko Wypędzeniom miało ukazać wyrwany z historycznego kontekstu obraz losu Niemców zmuszonych opuścić zamieszkiwane terytoria. Na fali szerokiej dyskusji przewartościowującej konsekwencje II wojny światowej dla Niemców mnożyć się zaczęły formalne roszczenia o zadośćuczynienia za poniesione szkody oraz straty materialne. Przeniesione na grunt dyskusji politycznej wyzwalały emocjonalne reakcje, w których bez trudu przekraczane były granice konstruktywnego dialogu. Jednoznaczne stanowisko biskupów z obu krajów stanowiło obronę nie tylko dotychczasowych dokonań na drodze pojednania, ale i wrażliwości oraz roztropności niezbędnej w życiu społecznym i relacjach osobowych. Podpisany przez przewodniczących obu episkopatów: abpa Józefa Michalika oraz kard. Karla Lehmanna dokument przestrzegał przed fałszywą sprawiedliwością, przywołując słowa Jana Pawła II - współautora Orędzia sprzed 40 lat - o sprawiedliwości mogącej łatwo stać się własnym zaprzeczeniem, jeśli zabraknie jej "głębszej mocy” - miłości. Dlatego w 2005 roku wzywano do przyznania się do całej prawdy i zaprzestania wyliczania krzywd oraz stwierdzano: „Odważne świadectwo chrześcijańskiego orędzia pojednania z roku

10 Wspólne oświadczenie konferencji Episkopatów Polski i Niemiec z okazji 40. rocznicy wymiany listów między oboma episkopatami w roku 1965, Fulda, 21 września 2005 r., Wrocław, 24 września 2005 r., tekst za: B. Kerski, T. Kycia, R. Żurek, „Przebaczamy i prosimy o przebaczenie”..., s. 225-229. 
1965 daleko wykroczyło poza obszar kontekstu polsko-niemieckiego". Świadectwo dotychczasowego dialogu było już wtedy oceniane jako zbyt cenne dla całej Europy, by pogrążyć je w niekończących się targach. Powinnością obu narodów ,jest zaangażowanie dla dobra wszystkich ludzi jednoczącej się Europy i wzmacnianie jej chrześcijańskiej tożsamości. To zadanie uda się wykonać tylko wtedy, gdy Niemcy i Polacy zrozumieją, że we wspólnej historii obu narodów tkwi także wiele dobra, które je łączy".

Kolejnym wspólnym dokumentem biskupów katolickich z Polski i Niemiec odwołującym się do treści oraz spuścizny Orędzia z 1965 roku było oświadczenie Przewodniczącego Konferencji Episkopatu Polski abp. dr. Józefa Michalika i Przewodniczącego Konferencji Episkopatu Niemiec abp. dr. Roberta Zollitscha $\mathrm{z}$ okazji 70. rocznicy rozpoczęcia II wojny światowej 1 września 1939 roku, sygnowane w Warszawie i Bonn 25 sierpnia 2009 roku $^{11}$, powtarzające sprawdzony już model trójpodziału na część dotyczącą wspomnienia i pamięci, kształtowania przyszłości oraz świadectwa i roli Kościoła. Także w tym dokumencie nie zabrakło odniesień i przestróg przed marnotrawieniem dorobku pojednania. Obok wskazania, iż pamięć o bolesnych wydarzeniach „wojny i czasów późniejszych” pozostaje żywa w relacjach między obu narodami, pojawiło się kategoryczne stwierdzenie: „W niektórych społecznych czy politycznych tendencjach ujawnia się również pokusa propagandowego wykorzystania raz już w historii zaistniałych zranień i pobudzania resentymentów wynikających z jednostronnych interpretacji historycznych. Kościół będzie nieustannie i zdecydowanie występował przeciw takiemu odejściu od prawdy historycznej. Zachęcamy do intensywnego dialogu, który zawsze łączy się z gotowością wysłuchania drugiej strony"12.

I tym razem uniwersalne wartości wspierające porozumienie między Polakami a Niemcami ukazane zostały w rocznicowym przesłaniu w znacznie szerszej perspektywie zjednoczonej Europy: „Pomimo pojawiających się niekiedy napięć i partykularnych nieporozumień, nieomijających rodziny narodów, warto pamiętać o fundamentalnym postępie dziejowym, wyrażającym się w integracji europejskiej. Nie wolno zaprzepaścić szansy budowania pokoju, jaką daje zjednoczenie narodów Europy”. Dokument z 2009 roku przypomniał po raz kolejny, że dar pojednania stanowi zobowiązanie w relacjach przekraczających wymiar bilateralny; podobnie europejska integracja

11 Oświadczenie Przewodniczącego Konferencji Episkopatu Polski abpa dra Józefa Michalika i Przewodniczącego Konferencji Episkopatu Niemiec abpa dra Roberta Zollitscha z okazji 70. rocznicy rozpoczęcia II wojny światowej 1 września 1939 roku, Tarnów 2009. 12 Tamże. 
wspólnoty narodów, choć $\mathrm{w}$ odniesieniu do Polski stanowi proces formalnie zamknięty, wymaga pogłębienia nie tylko w wymiarze politycznym, ale obywatelskim i aksjologicznym. Gdy polityczny i społeczny kształt Unii Europejskiej pozostaje obszarem sporów i kontrowersji, przypomnienie „niepolitycznej polityki” powinno wesprzeć starania o odzyskanie integrującego ducha i pokazać, że trwałość konstrukcji wymaga dochowania fundamentalnych wartości, kładąc nacisk nie tylko na wymiar polityczny, lecz obywatelski i poszerzający udział mechanizmów demokratycznych.

Czy spojrzenie z perspektywy drogi przebytej od 1965 roku do symbolizującego rzeczywisty przełom uścisku pojednania między premierem Tadeuszem Mazowieckim a kanclerzem Helmutem Kohlem w Krzyżowej w 1989 roku, aż po dynamiczną rzeczywistość polsko-niemieckiego sąsiedztwa w Unii Europejskiej nie redukuje słów biskupów do poziomu czysto symbolicznego, tym bardziej, że znamy sekwencję wydarzeń, które doprowadziły do fundamentalnych zmian na Starym Kontynencie?

Niewątpliwie nie o słowa tu chodzi, tym bardziej, iż trudno porównywać ich metapolityczny charakter $\mathrm{z}$ dokumentami rangi konstytucyjnej czy traktatowej, z deklaracjami dyktowanymi racją stanu czy autorytetem (słabnącym przecież) polityków. Nie było też, jak wspomniano wyżej i nie jest ambicją Kościołów zastępowanie polityków. Jako instytucja wolna od kalendarza wyborczego, może on ze znacznie bardziej zdystansowanych pozycji głosić prawdę i wzywać do konsekwentnej odpowiedzialności za nią: „Kościół nie musi starać się o reelekcję, nie działa w cyklach pięcioletnich, nie musi się ludziom podobać, dlatego też oferuje myślenie w dłuższej perspektywie, ale zarazem - wiedząc, że rozliczeni będziemy przy końcu czasu - zakłada również możliwość przyjścia Chrystusa w każdej chwili, a więc także przed następnymi wyborami. Oznacza to, że jesteśmy równie poważnie odpowiedzialni za każdą decyzję, którą dziś podejmujemy" ${ }^{13}$. Na przypomniane dokumenty należy więc patrzeć jako na wezwania do otwarcia, próby zrozumienia wielowątkowych racji każdego narodu i społeczności, a także wskazania aktualnych implementacji tych uniwersalnych nakazów w konkretnym wymiarze chwili: czy wśród uwarunkowań lat 60., w obliczu przełomu demokratycznego w Europie ${ }^{14}$, w perspektywie włączenia Polski do Unii Europejskiej,

13 P. Mazurkiewicz, Prawdziwy dialog jako podstawa relacji między Kościołami a Unia Europejska, [w:] S. Raabe (wyd.), Wkład chrześcijan w zjednoczenie Europy, Fundacja Konrada Adenauera, b.m.w. 2011, s. 72.

14 Por:J. Jauer, Urbi et Gorbi. Jakchrześcijanie wpłynęli na obalenie reżimu komunistycznego w Europie Wschodniej, Warszawa 2011. 
czy wreszcie w czasach, gdy „cud pojednania” przesłaniać zaczęły bieżące niedogodności, braki wzajemnego zrozumienia, narodowe egoizmy i próby instrumentalizacji w celu ochrony własnych interesów.

Spoglądając z mierzonej dekadami perspektywy, docenić należy także doświadczenia ostatnich lat, gdy niejednokrotnie relacje między Polakami a Niemcami kształtowały się odmiennie na szczeblu polityki międzynarodowej oraz kontaktów społeczeństw, organizacji czy samorządów. Zmiany koniunktury politycznej nie znajdowały odzwierciedlenia $\mathrm{w}$ stanie relacji między samorządami czy organizacjami pozarządowymi, a sieć wielorakich kontaktów okazała się wolna od kategorycznych nawet prób wpływania na nią przez polityków z pierwszych stron gazet. Trudno oszacować w wymierny sposób, jaki wpływ na ten stan rzeczy miały wezwania do porozumienia i pojednania formułowane także przez wspólnoty wyznaniowe. Bezsprzecznie jednak w warunkach wolności padły one na podatny grunt, wyzwalając inicjatywy oddolne pozwalające kreować trwałe płaszczyzny kontaktów między narodami. Umotywowane etycznie pryncypia znalazły czas swego urzeczywistnienia właśnie dzięki odzyskanej w 1989 roku wolności, a potencjał wynikający z procesu integracji europejskiej poszerzył i rozwinął możliwości wzajemnego poznania, porozumienia oraz budowania sieci nieskrępowanych kontaktów. Tyle razy powtarzane określenie „dobre sąsiedztwo”, obecne także na kartach umów międzynarodowych, przybrało właściwy wymiar, determinujący codzienne kontakty Polaków i Niemców.

Ogrom dokonanych zmian zasługuje na docenienie, choć pozostawia niedosyt i rozczarowanie; postawy społeczeństw i polityków wobec kryzysu uchodźczego, z jakim została skonfrontowana Europa w ostatnich latach są diametralnie różne w Polsce i Niemczech. Nie sposób uzasadniać nieprzychylności i zamknięcia się Polski na dramatyczną sytuację ludzi w potrzebie niedługim stażem państwa w Unii Europejskiej czy tylko względami bezpieczeństwa. Wartości chrześcijańskie, przywoływane w polityce częściej niż przed laty, kolejny raz stają się kwestią oczekującą poważnej odpowiedzi i podjęcia konsekwentnych działann ${ }^{15}$. Naszkicowane w dalszej części opracowania przyczynki do postawy, jaką wobec kryzysu migracyjnego zajęły Kościoły i społeczeństwo niemieckie wskazują na doświadczenia sąsiadów mogące zainspirować mieszkańców krajów po obu stronach Odry.

15 Patrz m.in. F. Montenegro, Wystapienie wprowadzające, [w:] Co nas łaczy, co nas dzieli w Europie? Rola Kościoła katolickiego w procesie integracji europejskiej, Gliwice 2015, s. 23 i n. 
Jest wreszcie jeszcze jeden powód, by spoglądać dziś na krętą drogę polsko-niemieckiego porozumienia jako rezerwuar doświadczeń. To uwaga i próby naśladowania sprawdzonych wzorców, z jakimi spotyka się ono dziś ze strony innych narodów Europy, a nawet świata. Trudno o proste analogie pomiędzy relacjami polsko-niemieckimi a mozolnym dialogiem z Rosjanami, warto jednak odnotować kroki, które i na tej drodze postawili przedstawiciele Kościołów ${ }^{16}$. Podobnie dzieje się w relacjach z Ukrainą - ważną w nich rolę odgrywają słowa zachęty wypowiedziane przez papieża Jana Pawła II, m.in. podczas wizyty we Lwowie w 2001 roku. Po ogłoszonym w 2005 roku w Warszawie i we Lwowie wspólnym liście Synodu Ukraińskiego Kościoła Greckokatolickiego i Konferencji Episkopatu Polski kolejną okazją była rocznica zbrodni wołyńskiej. Podpisana w Warszawie 28 czerwca 2013 roku w przededniu jej 70. rocznicy deklaracja Metropolity Kijowsko-Halickiego Ukraińskiego Kościoła Greckokatolickiego abp. Światosława Szewczuka oraz Przewodniczącego Konferencji Episkopatu Polski abp. Józefa Michalika, Przewodniczącego Konferencji Episkopatu Rzymskokatolickiego Ukrainy abp. Mieczysława Mokrzyckiego i abp. Jana Martyniaka, Metropolity Przemysko-Warszawskiego Kościoła bizantyńsko-ukraińskiego, wprost odwołuje się do wzorca Orędzia przebaczenia z $1965 \mathrm{roku}^{17}$. Ważne, że w ślad za deklaracjami podążają czyny wsparcia dla mieszkańców Ukrainy, w których istotne jest, że świadczona pomoc nie jest anonimowa, lecz stanowi okazję nawiązywania bezpośrednich kontaktów między społeczeństwami, jak działo się to w latach 80. przy okazji ogromnej pomocy materialnej świadczonej przez Niemców pogrążonej w kryzysie Polsce.

Warto też na marginesie wspomnieć, że doświadczenia porozumienia polsko-niemieckiego są $\mathrm{z}$ uwagą obserwowane przez przedstawicieli narodów tak odległych geograficznie i kulturowo, lecz borykających się w przeszłości z podobnie dramatycznymi i oczekującymi przepracowania konfliktami, jak Japończycy i Koreańczycy ${ }^{18}$.

16 Wspólne Przesłanie do Narodów Polski i Rosji, Przewodniczącego Konferencji Episkopatu Polski, Arcybiskupa Józefa Michalika, Metropolity Przemyskiego i Zwierzchnika Rosyjskiego Kościoła Prawosławnego Patriarchy Moskiewskiego i Całej Rusi Cyryla, podpisane 17 sierpnia 2012 r. $w$ Warszawie, http://episkopat.pl/dokumenty/pozostale/4396.1,Wspolne_Przeslanie_do_Narodow_Polski_i_Rosji.html (dostęp: 16.06.2016).

17 Tekst Deklaracji za: http://episkopat.pl/dokumenty/pozostale/5227.1,Deklaracja.html (dostęp: 16.06.2016).

18 The Search for Reconciliation: Korean-Japanese and German-Polish Relations since World War II, międzynarodowa konferencja zorganizowana przez Instytut Kultur 
Datujące się od ponad półwiecza działania Kościołów w Niemczech - zarówno ich hierarchii, jak i przedstawicieli różnorodnych grup laikatu - na rzecz porozumienia z Polakami można więc ocenić jako pewien model czy wzór, a jednocześnie wyzwanie. Najcenniejszym jego doświadczeniem jest zaangażowanie osób czy niewielkich nawet grup, które wierne swym przekonaniom działają nawet w niesprzyjających okolicznościach. Obok tej przysłowiowej „kropli drążącej skałę” ważna jest też świadomość, że pojednanie to zadanie bez końca - minione ćwierćwiecze uczy, jak łatwo ulec dawnym stereotypom i uprzedzeniom, stąd konieczność, by sfera uniwersalnych wartości przypominała o podstawach, na których tworzy się i rozwija pokojowe, stabilne współistnienie narodów i społeczeństw ${ }^{19}$.

\section{Kościoły Niemiec wobec kryzysu migracyjnego}

Diagnoza sytuacji dotyczącej liczby napływających do Niemiec migrantów skazana jest na szybką dezaktualizację. Do końca 2015 roku do Niemiec przybyło ok. 1,1 mln osób; szacunki na rok 2016 mówiły o ok. 800 tys. osób, a na lata kolejne po ok. 500 tys. osób rocznie. Na marginesie można dodać, że skumulowane wydatki związane z przyjęciem migrantów w latach 20152017 szacowane są na 56 mld euro ${ }^{20}$. Jest oczywiste, że o ile środki finansowe na pokrycie tych niebagatelnych sum płyną zarówno z budżetu federalnego, jak i zasobów poszczególnych krajów federacji, to decyzje o przyjęciu, udostępnieniu miejsc pobytu i organizacji elementarnej opieki zapadać muszą na szczeblu najniższym - organizacji, gmin i społeczności lokalnych. Kluczowe, nie tylko ze względu na pierwszy kontakt z przybyłymi, ale także akceptację przez mieszkańców przyjmujących gmin i społeczności są zatem nie tylko udostepnienie miejsc i zaoferowanie wsparcia, ale przede wszystkim działania

Śródziemnomorskich i Orientalnych PAN oraz Fundację Konrada Adenauera w Polsce, Warszawa 27 października 2015 r.

19 Por. O. Karas, Wartości chrześcijańskie jako punkty orientacyjne w czasie kryzysu, [w:] S. Raabe (wyd.), Chrześcijańska odpowiedzialność w obliczu kryzysów. Wyzwania w polityce, w porzadku społeczno-gospodarczym, w kulturze i komunikacji, Fundacja Konrada Adenauera, b.m.w. 2010, s. 35-40; E. Balestrero, Wkład chrześcijan w polizbońska Europe, [w:] Etyczny wymiar polityki. Rola Kościoła katolickiego w procesie integracji europejskiej, Gliwice 2012, s. 63-69.

20 Por. T. Budnikowski, Republika Federalna Niemiec: rosnące koszty napływu uchodźców, „Biuletyn Instytutu Zachodniego”, Seria specjalna „Uchodźcy w Europie”, 2016, nr 228 z 21 marca 2016 r., http://www.iz.poznan.pl/news/1395_228_koszty_uchodzcy.pdf (dostęp: 21.07.2016). 
rzeszy osób pracujących dla przybyszy. Wzmacnia to aprobatę dla podjętych działań i pomaga niwelować uprzedzenia, strach czy niechęć wynikłe z nieznajomości. Ten pierwszy krok do późniejszej integracji jest istotny nie tylko dla przybyłych, ale i przyjmujących.

„Ucieczka, wypędzenie oraz utrata ojczyzny są charakterystycznymi znakami naszych czasów" (Flucht, Vertreibung und Heimatverlust sind prägende Zeichen unserer Zeit) - słowa otwierające opublikowane 18 lutego 2016 roku wytyczne dla zaangażowania Kościoła na rzecz uchodźców (Leitsätze des kirchlichen Engagements für Flüchtlinge) Niemieckiej Konferencji Biskupów (Deutsche Bischofskonferenz, dalej DBK) zakorzenione są w dwudziestowiecznym doświadczeniu Niemiec i Europy, choć przecież historyczna geneza tych zjawisk sięga znacznie wcześniejszych czasów. Zaraz po nich pada też zdecydowana deklaracja: „My chrześcijanie nie możemy pozwolić, byśmy zostali tym zarażeni. »Bardziej niż kiedykolwiek sumieniami ludzkimi powinna dziś wstrząsać Ewangelia Miłosierdzia - wpisał nam papież Franciszek ku pamięci. »Globalizacja miłości« ma swoje miejsce także w naszym najbliższym sąsiedztwie. Nadzieje i obawy wielu ludzi poszukujących ochrony są w sposób szczególny nadziejami i obawami Kościoła"21. Podobieństwo tego końcowego sformułowania do słów Konstytucji Duszpasterskiej o Kościele w świecie współczesnym Gaudium et spes Soboru Watykańskiego II $^{22}$ nie jest z pewnością przypadkowe i nie jest tylko przejawem retorycznej kurtuazji inspirowanej jubileuszem półwiecza, jakie upłynęło od zakończenia obrad soborowych. Warto zwrócić uwagę na ten związek, gdyż kryzys migracyjny jest jednym $\mathrm{z}$ wielu wyzwań, wobec których staje Kościół katolicki, a wskazówek dotyczących jego postawy należy poszukiwać także we wspomnianym już soborowym aggiornamento - otwarciu się na potrzeby świata i podejmowaniu konkretnych działań, które zaradzając jego potrzebom, stwarzają

21 „Wir Christen dürfen uns davon nicht anstecken lassen. 'Mehr denn je rüttelt das Evangelium der Barmherzigkeit heute die Gewissen der Menschen wach', hat Papst Franziskus uns ins Stammbuch geschrieben. Die 'Globalisierung der Nächstenliebe' - sie hat ihren Ort heute auch in unserer unmittelbaren Nachbarschaft. Die Hoffnungen und Ängste der vielen schutzsuchenden Menschen sind in besonderer Weise auch die Hoffnungen und Ängste der Kirche”. Deutsche Bischofskonferenz, Leitsätze des kirchlichen Engagements für Flüchtlinge, Arbeitshilfen 2016, nr 282, s. 4.

„Radość i nadzieja, smutek i trwoga ludzi współczesnych, zwłaszcza ubogich i wszystkich cierpiących, są też radością i nadzieją, smutkiem i trwogą uczniów Chrystusowych; i nie ma nic prawdziwie ludzkiego, co nie miałoby oddźwięku w ich sercu" - początkowe słowa Gaudium et spes, [w:] Sobór Watykański II, Konstytucje, dekrety, deklaracje, Poznań 2002, s. 526. 
jednocześnie okazję autentycznego przekazu postawy i wartości chrześcijańskich. Szacowana na początku 2016 roku na ok. 5 tys. pracowników etatowych oraz ok. 100 tys. wolontariuszy rzesza osób zaangażowanych w pomoc uchodźcom i migrantom świadczoną przez instytucje tylko Kościoła katolickiego w Niemczech jest wymownym świadectwem takiej postawy.

Wspomniany wyżej dokument $D B K$ ujmuje syntetycznie dwie podstawowe kwestie: pierwsza, adresowana bardziej ad intra, to argumenty uzasadniające zaangażowanie instytucji i członków Kościoła w pomoc uchodźcom, druga natomiast to próba zarysu konkretnych obszarów zaangażowania. Troska o uchodźców pojmowana jest przede wszystkim jako wyraz samoświadomości Kościoła, a jej miarą jest pozytywna odpowiedź na pytanie, czy każdy przybyły jest traktowany zgodnie z ludzką godnością. Świadczona pomoc realizowana jest na wszystkich poziomach aktywności Kościoła, przez wiele podmiotów i przy wykorzystaniu ich zróżnicowanych kompetencji (tu przywołana jest zasada subsydiarności). Zasadą przyświecającą zaangażowaniu Kościoła w pomoc uchodźcom jest dążenie do tego, by była to okazja do spotkania osób i nawiązania bezpośrednich kontaktów. Jednocześnie podkreśla się, że instytucje i stowarzyszenia kościelne są tylko jednymi z wielu podmiotów świadczących pomoc i nie powinny być traktowane jako substytuty (Ersatz) powołanych do pomocy instytucji socjalnych oraz obywatelskich. Podobnie podejmowana pomoc dla uchodźców nie oznacza zaniechania czy ograniczenia zwyczajnych, dotychczasowych działań na rzecz potrzebujących - w tym kontekście pada znów sformułowanie zaczerpnięte $\mathrm{z}$ katolickiej nauki społecznej, określające pomoc migrantom mianem odczytania znaków czasu, gdy solidarność obejmująca kompleksowe spojrzenie na problemy społeczne zobowiązuje zarówno do kontynuowania zwyczajnych dzieł charytatywnych, jak i podjęcia wyzwań chwili.

Dokument niemieckiego episkopatu zwraca uwagę na integrację rzeszy migrantów jako ogólnospołeczne zadanie i przyjmuje rolę Kościoła jako odpowiedzialnego za powodzenie tego procesu. Powołuje się w tym miejscu na bogate i wieloletnie doświadczenie, wynikające przede wszystkim z natury Kościoła katolickiego jako wspólnoty wielu języków i narodów, a także z wieloletniego już doświadczenia dialogu chrześcijaństwa i islamu oraz wspólnot wyznaniowych i świata podlegającego procesom sekularyzacji. Warto $\mathrm{w}$ tym miejscu zwrócić uwagę na specyfikę RFN jako państwa, w którym niełatwy i daleki od spektakularnych sukcesów dialog z islamem prowadzony jest systematycznie zarówno przez Kościoły, jak i przez państwo (czego wyrazem jest Niemiecka Konferencja ds. Islamu - powołana w 2006 roku pod auspicjami ministra spraw wewnętrznych płaszczyzna stałego dialogu z organizacjami muzułmańskimi). 
W drugiej części Leitsätze des kirchlichen Engagements für Flüchtlinge zawarte zostały postulaty kierowane do kościelnych organizacji i instytucji zaangażowanych w pomoc uchodźcom. Położono w nich nacisk na wzmocnienie kompetencji zarówno etatowych pracowników, jak i wolontariuszy, wychodząc z słusznego założenia, iż służą one nie tylko sprawnej pracy, ale i budowaniu zaufania, unikaniu uprzedzeń i eliminowaniu lęków adresatów świadczonej pomocy. Niemałych problemów dostarczają kwestie związane z opieką duszpasterską i to nie tylko dlatego, że wielu uchodźców to muzułmanie. Wśród ich chrześcijańskiej części wielu przynależy do Kościołów wschodnich, które choć zachowują łączność z Rzymem, to posługują się odrębnymi rytami, dla których nie zawsze łatwo jest znaleźć w Niemczech duszpasterzy, a podobne problemy dotykają także chrześcijan prawosławnych. Na mozaikę religijną i wyznaniową nakłada się, jeszcze bardziej istotny, problem zróżnicowania językowego.

Kościół jako instytucja udzielająca migrantom schronienia we własnych obiektach, także tymczasowo przystosowanych do zamieszkania, świadom jest przejściowego charakteru tych rozwiązań. Utrzymanie takiej sytuacji niesie bowiem ryzyko powstania izolowanych gett, które przeczą idei integracji przybyszów. Dlatego zadanie znalezienia dachu nad głową dla migrantów pozostaje otwarte. Doświadczenie poszukiwania mieszkań dla uciekinierów przybyłych do Niemiec po zakończeniu II wojny światowej wskazuje na konieczność podjęcia przez Kościół - jako jeden z licznych podmiotów niosących pomoc - współpracy z instytucjami socjalno-charytatywnymi, administracją osiedli i gruntów, sektorem finansów. Poszukiwanie stabilnych rozwiązań jest konieczne także w zakresie zatrudnienia, kształcenia, uznania kwalifikacji bądź dokształcenia pracowników, a także wsparcia pracodawców przyjmujących migrantów (również w zakresie potwierdzenia kwalifikacji). To kolejna sfera, w której cenne są doświadczenia i instytucje funkcjonujące od lat pod egidą Kościołów (jak choćby ośrodki doradztwa czy spółdzielnie socjalne), z powodzeniem działające na rynku pracy. Nauka języka, choć istotna, nie jest bowiem jedynym problemem $\mathrm{w}$ perspektywie zakotwiczenia przybyszów w nowym środowisku. $\mathrm{W}$ odniesieniu do młodszych, pilne jest podjęcie edukacji od najniższych szczebli. W tym kontekście warto też zwrócić uwagę na dylematy związane $\mathrm{z}$ niemieckim systemem edukacji oraz szkolnictwem zawodowym. Przyjęcie uchodźców stawia pod znakiem zapytania plany odejścia od modelu kształcenia dualnego (nauka i praktyka) w cieszących się coraz mniejszym zainteresowaniem uczniów Hauptschule. Zachował się on tylko w Bawarii, Saksonii i Brandenburgii, w pozostałych krajach federacji dominuje model kształcenia ogólnego (gimnazjalny). Tymczasem model kojarzony z Hauptschule jest znacznie korzystniejszy, zarówno 
jeśli uwzględni się obecny napływ migrantów do RFN oraz jego następstwa dla systemu edukacji, rynku pracy i integracji społecznej ${ }^{23}$.

Inną dziedziną zarówno doraźnej, jak i długoterminowej pomocy jest opieka i ochrona zdrowia, w tym wsparcie psychologiczne. Skala możliwych do oszacowania potrzeb nakazuje już dziś rozwijanie takich ośrodków i instytucji prowadzonych pod auspicjami Kościoła. W dokumencie $D B K$ wyodrębniona została także pomoc i ochrona kobiet i dziewcząt - zarówno jako ofiar, jak i potencjalnie bardziej narażonych na nadużycia seksualne.

Na uwagę i uznanie zasługuje podkreślenie, że pomoc uchodźcom stanowi formę dialogu międzyreligijnego i interkulturowego - nie tylko w relacji do przybyszów, ale wobec wielu podmiotów i grup świadczących tę pomoc, a są wśród nich także organizacje islamskie oraz żydowskie. Stanowisko tych ostatnich, reprezentowanych przez Centralną Radę Żydów w Niemczech i jej przewodniczącego Josefa Schustera, który już w kwietniu 2015 roku oświadczył, ze Niemcy nie mogą sobie pozwolić na to, by nie przyjąć uchodźców, a pół roku później obrazowo stwierdził, że pierwszym krokiem do integracji mogłoby być adresowane do nich wydanie Ustawy Zasadniczej w języku arabskim $^{24}$, do publikacji której faktycznie doszło w listopadzie 2015 roku nakładem Federalnej Centrali Kształcenia Politycznego ${ }^{25}$. Licząc na akceptację przez przybywających podstaw porządku ustrojowego oraz społecznego, jak i na współdziałanie innych państw europejskich w przyjęciu migrantów, Schuster mówił o tym wyzwaniu dla Niemiec w kategoriach „humanitarnej powinności", wynikającej również z doświadczenia historycznego.

Międzynarodowe współdziałanie, zmierzające do zażegnania przyczyn migracji, zaakcentowane zostało także $\mathrm{w}$ omawianym dokumencie roboczym $D B K$. Podkreśla on, że towarzysząca obecnemu kryzysowi międzynarodowa dyskusja zdaje się nie dostrzegać, że uchodźcy w pierwszej kolejności poszukują schronienia i bezpieczeństwa bliżej swych ziem rodzinnych, a nie znajdując ich tam, kierują się w ostateczności do Europy.

23 Por. M. Balcerek-Kosiarz, Ryzyko wzrostu zadłużenia krajów związkowych i gmin z powodu kryzysu uchodźców w Niemczech, „Biuletyn Instytutu Zachodniego”, Seria specjalna „Uchodźcy w Europie”, 2016, nr 232 z 8 kwietnia 2016 r., http://www.iz.poznan.pl/news/1409_232_uchodzcy_zadluzenie_Niemcy.pdf (dostęp: 17.07.2016). Sie müssen unsere Grundordnung anerkennen, Zentralratspräsident Josef Schuster über Flüchtlinge, Aufnahmemöglichkeiten und Integration - Interview mit der Jüdischen Allgemeinen online, 1.10.2015, http://www.zentralratdjuden.de/de/article/5414.sie-müssen-unsere-grundordnung-anerkennen.html (dostęp: 14.04.2016).

25 Patrz: http://www.bpb.de/shop/buecher/grundgesetz/215136/grundgesetz-auf-arabisch (dostęp: 14.04.2016). 
Odnosząc się w końcu do sfery polityki, biskupi niemieccy zwrócili uwagę, że zaangażowanie Kościoła w pomoc uchodźcom i migrantom nie zwalnia państwa z podejmowania zarówno prawnych, społecznych, jak i praktycznych działań służących zaradzeniu temu wyzwaniu. Ponieważ jednak zasadnicza motywacja wypływa z przesłanek etycznych, Kościół nie tylko angażuje się w miarę swoich możliwości w świadczenie pomocy, ale także z uwagą śledzi podejmowanie działania prawne i polityczne, w przeświadczeniu, że warunki kryzysu nie zwalniają z obowiązku utrzymania standardów prawnych, humanitarnych oraz socjalnych. Podobnie jak ochrona rodziny, należą one do podstawowych wyznaczników pomocy świadczonej każdemu, nawet tym, którzy nie traktują Niemiec jako miejsca swego długoterminowego czy stałego pobytu.

Wypowiedzi przedstawicieli największych Kościołów oraz podejmowane przez ich instytucje działania oparte są na wieloletnim doświadczeniu pomocy charytatywnej imigrantom, a także ofiarom kryzysów humanitarnych, choć towarzyszy im świadomość bezprecedensowych rozmiarów obecnego kryzysu. Popularne stwierdzenie, iż wyróżnikiem niemieckich Kościołów w świecie są pochodzący z tego kraju teologowie oraz pieniądze, w obliczu obecnej sytuacji kolejny raz dowodzi niestosowności tonu takich opinii. Doświadczenia wielkich fundacji charytatywnych (Adveniat, Missio, Misereor, Renovabis, Kirche in Not), katolickiej Caritas i ewangelickiej Diakonii stanowią dziś fundament pracy na rzecz przybywających do Niemiec migrantów i uchodźców. Inaczej niż dla instytucji państwowych, dla wspólnot religijnych przybysze stają się nie kimś z zewnątrz, lecz podopiecznymi czy współbraćmi - jak zauważył biskup krajowy Kościoła Ewangelicko-Luterańskiego w Bawarii Heinrich Bedford-Strohm, jego wierni pochodzą ze 166 narodów, a jedna dziesiąta $\mathrm{z}$ nich urodziła się poza granicami Niemiec ${ }^{26}$. Sprzeciw Kościołów wobec prób odgradzania się Europy - czasem nawet dosłownego, za pomocą ogrodzeń i strzeżonych granic - od zmierzających do niej uchodźców idzie w parze z działaniami służącymi niwelowaniu obaw i poczucia zagrożenia wśród mieszkańców Niemiec. Obok licznie angażujących się wolontariuszy i etatowych pracowników instytucji pomocowych podejmowane są działania kształtujące postawy i opinie, także za pomocą narzędzi duszpasterskich, np. materiałów pomocniczych do sprawowania liturgii, zarówno

26 EKD-Ratsvorsitzender Bedford-Strohm: Militärische Grenzanlagen für Europa sind eine „Horrorvision“, „epd-Meldungen”, 19. April 2016, http://www.ekd.de/aktuell_ presse/news_2016_04_19_03_bedford-strohm_grenzanlagen_europa.html (dostęp: 14.06.2016). 
w języku niemieckim jak i w językach arabskim, perskim, rosyjskim, francuskim, angielskim ${ }^{27}$.

Zakres świadczonej pomocy materialnej jest trudny do oszacowania, zarówno ze względu na dynamikę napływu migrantów, jak i mnogość instytucji świadczących pomoc. Warto zauważyć, że nie zaniedbuje się przy tym sfery public relations, a trafiające do opinii publicznej informacje stanowią nie tylko zachętę do włączenia się kolejnych pracowników czy wolontariuszy, ale w szerszej perspektywie ukazują konstruktywne działania podejmowane na rzecz rozwiązania kryzysowej sytuacji. Każdy przykład dowodzi, jak złożonym problemem jest przyjmowanie tak wielkiej rzeszy ludzi: np. przypadek 50-tysięcznego Schwerte w Nadrenii-Północnej Westfalii, które przyjęło 700 uchodźców i wydało na ich utrzymanie do końca 2015 roku 4,6 mln euro. Środki uzyskane z kasy kraju związkowego wyniosły tylko $3,1 \mathrm{mln}$, resztę sfinansowano kredytem, co może zagrozić finansom gminy. Inna liczba obrazująca sytuację w Schwerte to 400 wolontariuszy pracujących dla przybyszy ${ }^{28}$. Za przykład pomocy udzielanej przez diecezje katolickie może posłużyć niewielkie Eichstätt położone w Jurze Frankońskiej. Jest stolicą diecezji zamieszkiwanej przez ok. 900 tys. ludzi, spośród których ok. 405 tys. to katolicy (dane za 2014 rok). W 275 parafiach pracuje 291 duchownych (z czego 99 w wieku emerytalnym), na terenie diecezji pracuje też 400 zakonnic, 84 zakonników oraz 49 referentów pastoralnych, 62 referentów parafialnych oraz 143 katechetów. Udział wiernych świeckich uczęszczających do kościoła szacowany jest na 16,4 procent. O potencjale diecezji świadczy nie tylko fakt, że Eichstätt jest siedzibą Katolickiego Uniwersytetu, seminarium duchownego oraz Collegium Orientale, ale również działalność 10 towarzystw kształceniowych (Bildungswerke), trzech domów konferencyjnych, 10 szkół katolickich oraz licznych instytucji opiekuńczo-społecznych (m.in. 22 domy starców, 189 przedszkoli, powiatowe stacje Caritas, Pomoc Maltańska, poradnie dla młodzieży, kobiet oraz rodzin i in. $)^{29}$. Utrzymująca tak wiele instytucji diecezja, dysponująca w 2016 roku budżetem w wysokości ok. 151 mln euro (z których ok. 102 mln euro to wpływy z podatku kościelnego), a największa część

27 Patrz m.in. materiały udostępnione na stronie internetowej EKD: http://www.ekd. de/themen/gottesdienst-und-migration/index.html (dostęp: 14.04.2016).

Por. T. Budnikowski, Republika Federalna Niemiec: rosnace koszty napływu uchodźców, „Biuletyn Instytutu Zachodniego”, Seria specjalna „Uchodźcy w Europie”, 2016, nr 228 z 21 marca 2016 r., http://www.iz.poznan.pl/news/1395_228_koszty_uchodzcy.pdf (dostęp: 08.04.2016).

29 Patrz: http://www.bistum-eichstaett.de/zahlen/ (dostęp: 08.04.2016). 
wydatków - $78 \mathrm{mln}$ euro - to koszty osobowe, roztoczyła jesienią 2014 roku opiekę nad grupą ok. 300 uchodźców. Rolę Erstaufnahmeeinrichtung spełniają usytuowane w centrum miasta budynki przeniesionej $\mathrm{w}$ inne miejsce katolickiej Maria-Ward-Realschule. Według pierwotnych zamysłów do budynku miały się wprowadzić rozproszone po zabytkowym centrum urzędy kurialne, jednak decyzją biskupa Gregora Marii Hankego OSB, tymczasowo obiekt został udostępniony potrzebującym. Grupa najmłodszych jego mieszkańców w wieku od 8 do 16 roku życia korzysta od stycznia 2016 roku z zajęć szkolnych (Willkommensklasse) w Maria-Ward Schule, początkowo $\mathrm{w}$ wymiarze 4 godzin dziennie, celem zaznajomienia się z niemieckim systemem szkolnictwa i nauki języka. Działania wymagające sporej aktywności oraz środków, nie są jedynymi świadczonymi przez frankońskich chrześcijan. Przykładem wybiegającym poza granice diecezji Eichstätt jest ich pomoc świadczona m.in. przez Pomoc Maltańską na rzecz potrzebujących w Iraku ${ }^{30}$. W ślad za praktyczną pomocą idą też inicjatywy edukacyjne, wykłady otwarte dotyczące ekumenii i dialogu międzyreligijnego czy sytuacji chrześcijan na Bliskim Wschodzie.

Przywołany przykład diecezji Eichstätt z pewnością nie jest miarodajny; dotyczy bowiem Bawarii - kraju federacji o relatywnie największych wskaźnikach religijności, jak i zamożności. Z drugiej jednak strony należy uwzględnić fakt, że i Bawarii nie są obce problemy malejącego zaangażowania wiernych w życie Kościoła, formalne wystąpienia zeń (znajdujące swoje odbicie we wpływach $\mathrm{z}$ podatku kościelnego, a co za tym idzie, w środkach pozostających do dyspozycji instytucji kościelnych). Sytuacja ta wzmacnia jednak zasygnalizowaną na wstępie tezę, że oceny życia religijnego współczesnych Niemiec nie mogą ograniczać się do analizy danych statystycznych. Przykład działań podejmowanych na rzecz uchodźców i migrantów - przede wszystkim osobiste zaangażowanie wielu pracowników i wolontariuszy organizacji charytatywnych - dowodzi, że miarą żywotności religii są przede wszystkim postawy ludzkie.

\section{Podsumowanie}

Ćwierć wieku po zjednoczeniu Niemiec obraz ich życia religijnego tworzy niezwykle zróżnicowaną mozaikę i daleki jest od tradycyjnego postrzegania tego kraju przez pryzmat tradycji protestanckiej północy oraz katolickiego

30 Patrz: http://www.bistum-eichstaett.de/aktuell/aktuelle-meldungen-details/news/malteser-sammeln-fuer-christen-im-irak-spende-an-bischof-hanke-uebergeben/ (dostęp: 16.06.2016). 
południa. Za powierzchowne uznać też należy oceny diagnozujące kondycję religii w Niemczech wyłącznie na podstawie statystyk, które zresztą dzięki systemowi egzekwowanego za pośrednictwem państwa podatku kościelnego pozwalają na precyzyjne określenie liczby członków poszczególnych związków wyznaniowych. Dwie wybrane, przedstawione powyżej kwestie - zadanie pojednania $\mathrm{w}$ dialogu i porozumieniu między narodami oraz pomoc uchodźcom i migrantom - pokazują, że miarą żywotności wspólnot konfesyjnych jest przede wszystkim ich gotowość zaangażowania się w działania wychodzące naprzeciw bieżącym wyzwaniom - owym „znakom czasu”, na które odpowiedź jest autentycznym dowodem postaw inspirowanych wyznawanymi wartościami. To sfery trudniejsze do uchwycenia w jednoznacznych statystykach, ale dopełniające bogatego obrazu aktywności wspólnot religijnych współczesnych Niemiec i nie pozwalające na marginalizowanie ich roli.

\section{Zusammenfassung}

Das differenzierte Bild des religiösen Lebens ist ein Vierteljahrhundert nach der Wiedervereinigung Deutschland weit von der traditionellen Wahrnehmung des Landes durch den Gesichtspunkt der Tradition der protestantischen Norden und dem katholischen Süden. Die Beurteilungen der Diagnose des Zustands der Religion in Deutschland sind oberflächlich nur auf der Grundlage von Statistiken. Zwei ausgewählte Themen - die Aufgabe der Versöhnung, des Dialogs, der Verständigung zwischen den Völkern wie auch die Hilfe für Flüchtlinge und Migranten - zeigen, dass ein Maß für die Vitalität der konfessionellen Gemeinden in erster Linie die Bereitschaft ist, sich an Aktivitäten zu beteiligen, die die aktuellen Herausforderungen zu bewältigen ermöglichen.

\section{Bibliografia}

BALESTRERO E., Wkład chrześcijan w polizbońska Europę, [w:] Etyczny wymiar polityki. Rola Kościoła katolickiego w procesie integracji europejskiej, Gliwice 2012.

BIULETYN Instytutu Zachodniego, seria specjalna „Uchodźcy w Europie” 2016, nr 232.

BRAUDEL F., Historia i trwanie, Warszawa 1971.

DOBROWOLSKA-POLAK J., JACKOWSKA N., NOWOSIELSKI M., TUJDOWSKI M. (red.), Niemcy po zjednoczeniu. Społeczeństwo - wielokulturowość - religie, Poznań 2013.

JAUER J., Urbi et Gorbi. Jak chrześcijanie wptynęli na obalenie reżimu komunistycznego w Europie Wschodniej, Warszawa 2011. 
Pojednanie i Caritas. Kościoły w życiu społecznym zjednoczonych Niemiec...

KATHOLISCHE Kirche in Deutschland, Zahlen und Fakten 2014/2015, Arbeitshilfen, nr 275.

KERSKI B., KYCIA T., ŻUREK R., GÓRNY J. (red.), „Przebaczamy i prosimy o przebaczenie”. Orędzie biskupów polskich i odpowiedź niemieckiego episkopatu z 1965 roku. Geneza, kontekst, spuścizna, Olsztyn 2006.

LEITSÄTZE des kirchlichen Engagements für Flüchtlinge, Arbeitshilfen 2016, nr 282.

MADAJCZYK P., Na drodze do pojednania. Wokół orędzia biskupów polskich do biskupów niemieckich $z 1965$ roku, Warszawa 1994.

O WOLNOŚĆ, sprawiedliwość i pokój w Europie. Oświadczenie katolików polskich i niemieckich $w$ pięćdziesiąta rocznice wybuchu II wojny światowej, Warszawa-Bonn, sierpień 1989 r., „Więź” 1989, nr 9.

RAABE S. (wyd.), Chrześcijańska odpowiedzialność w obliczu kryzysów. Wyzwania $w$ polityce, $w$ porządku społeczno-gospodarczym, $w$ kulturze i komunikacji, Warszawa 2010.

RAABE S. (wyd.), Wkład chrześcijan w zjednoczenie Europy, Warszawa 2011. SOBÓR Watykański II, Konstytucje, dekrety, deklaracje, Poznań 2002.

WSPÓLNE słowo polskich i niemieckich biskupów z okazji trzydziestej rocznicy wymiany listów (1965-1995), „Społeczeństwo” 1995, nr 4.

http://bistum-eichstaett.de

http://ekd.de

http://episkopat.pl

http://zentralratdjuden.de 